\title{
INDIVIDUAL STYLE OF ACTIVITY: THE HISTORY OF THE CONCEPT AND ITS PLACE IN THE MODERN PSYCHOLOGY OF EDUCATION
}

\author{
Marina Pakhmutova ${ }^{1^{*}}$, Svetlana Bakhtina ${ }^{2}$, Svetlana Andreeva ${ }^{3}$, Tatyana \\ Golovanova $^{4}$ \\ ${ }^{1} \mathrm{PhD}$ student, Mari State University, Russia, quora2011@yandex.ru \\ ${ }^{2}$ Associate professor, Mari State University, Russia, basvet56@mail.ru \\ ${ }^{3}$ Associate professor, Mari State University, Russia, swetlana64@list.ru \\ ${ }^{4}$ Associate professor, Mari State University, Russia, tatahanum904@gmail.com \\ ${ }^{*}$ Corresponding author
}

\begin{abstract}
The article examines several approaches to studying the phenomenon of "style", that exist in modern psychology. Some researchers associate the concept of "style" with the adaptive mechanisms of the human psyche (A. Adler, R. Stagner), others consider "style" as part of the system of interaction of the subject with the environment (V. Tolochek, B. Vyatkin).

The article describes the development of the semantics of the concept of "style" in psychological researches. Originally, this concept appeared in the works of A. Adler, G. Allport and was associated with the growing interest of society in the individuality of man. Understanding that each person has a peculiar style, opened the possibility of knowing the depth and diversity of the inner world of a man. But the main issue - the opposition of the individuality of a person to the influence of society - remained unresolved (Z. Freud, B. Skinner).

The representatives of Soviet psychology actively engaged in the same issue in the early of the twentieth century. They solved the problem of increasing the efficiency of labor without personal deformation of the worker and through the disclosure of his potential (A. Gastev, V. Bekhterev). One of the results of this work was the emergence of the concept of "individual style of activity", which reflected the ability of the subject to develop personal qualities in accordance with the requirements of the activity and at the same time to change the conditions of activity in accordance with their ideas about achieving the goal.

The article analyzes the place and role of the concept of "individual style of activity" from the point of view of the psychology of education. Formation of an individual style of activity begins from the moment of inclusion of the subject in public activity and continues throughout all stages of training. Being manifested in educational activity, individual style of activity is then transferred to the field of specialized activity. Upon completion of training, the individual style of activity becomes a condition for the graduate's readiness to perform professional duties.

The article substantiates the use of the concept of "individual style of activity" in the psychology of education, which will make it possible to effectively design a system of psychological and pedagogical support for the professional development of students taking into account their individual characteristics.
\end{abstract}

Keywords: individual style, activity, psychology of education, professional development. 


\section{INTRODUCTION}

Interest in the individual style of activity is typical for Russian psychology from the 50s-60s (Klimov, 2003). The relevance of this topic is still maintained today in connection with the growing demands of the society for improving the quality of human capital, developing the talent potential (Andreeva, Bakhtina, 2013, pp. 138143), the formation of new worldviews (Golovanova, 2004, p. 13).

In foreign psychology, a major contribution to the study of style was made by cognitive science, which describes various ways of obtaining and processing information by a person depending on its individual characteristics. These questions in the aspect of the style of learning and the style of thinking have developed in modern education psychology (Bakhtina and Belyanina, 2008, p. 48). The use of innovative technologies for the development of professional competencies does not always take into account the dynamics and characteristics of the personal development of students. The diffusion of the value-semantic sphere prevents the full disclosure of the subject in the professional field. Therefore, the use of the concept of style of activity and learning technologies, taking into account the individual style of students, will solve many issues of educational psychology.

\section{LITERATURE REVIEW}

\subsection{Formation of the concept of "style" in the humanities}

In the sociological tradition, style is a collection of the behavior patterns of an individual or a group, oriented primarily to everyday life. The basis for shaping the lifestyle of a particular person are the needs: biological, emotional, social. With the same content, the concept of "style" came to psychology. A. Adler described the lifestyle as a ratio of social interest and the desire for domination (Adler, 2011, p.7). In the psychoanalytic concept, the relationship between style and conditions of life is examined. It is believed that formation of style begins when a person unconsciously resorts to different forms of compensation for his physical and mental deficiencies.

In the 80-ies of the twentieth century there was a tendency to hyper-aggregation of the concept of "style" and its spread to all areas of the person's mental and social life. In particular, the concept of cognitive style has expanded through the emergence of new meanings, such as "style of thinking", "style of learning".

Foreign approaches to the concept of "style" are connected with the desire to describe the personality of the individual through her thinking, behavior, creativity, self-realization. The actual activity aspect of the style is connected with the works of Russian scientists and is based on the unity of consciousness and activity (Lezhnina, 2007, pp. 33-35).

\subsection{Individual style of activity}

The study of the individual style of activity is associated, on the one hand, with the development of the activity approach, and on the other with the study of the integral individuality (Pakhmutova, 2015, pp. 72-81). A double aspect of this problem was formed in the process of studying the adaptation of the individual.

Some researchers described various methods of adaptation as the success or failure of activity in changed conditions. Others believed that adaptation contributed to a change in the qualities of the individual at different levels of her organization and the dynamics of personality development. The transition to the notion "style of activity" made it possible to define various strategies for adapting a person to changing conditions, and also to study the specifics of individual changes.

In the tradition of the Perm school, "style" was viewed as a psychological system, the formation and functioning of which is associated with the emergence of a person's individuality. As a psychological phenomenon, the style is "a stable psychological system that ensures the coordination of individual characteristics of a person with the conditions and requirements of activities, environments, ensuring the success of the subject's activity" (Tolochek, 2015, p. 72).

The result of researches of Russian scientists became the description of the style of activity as a coordinated system of goals, actions and operations of objective activity. More recent studies have shown that the individual style of activity includes properties not only of the psychodynamic level, but also of the personal level (values attitudes, meanings). Modern research has revealed that the success of the activity is determined not so much by the components of the style as by its organization. If such an organization is constructive, then the activity is successful, but if it is not constructive, then the activity ends with a negative result. 
Thus, the individual style of activity has a structurally functional organization that includes different levels of active and passive adaptation of a person to the environment. Individual style of research activity can be reflected in various personal properties: psychodynamic, operational, value-semantic. (Khinkanina and Serova, 2016, pp. 5942-5950). The main question is how the attitude of the subject to the activity and his personality quality is manifested in an individual style.

\section{MATERIALS AND METHODS}

The purpose of our study was to determine the characteristics of individual styles of students' activities. The research hypothesis consisted of the assumption that modern students realize their educational activity through two styles, which differ in the degree of responsibility, level of organization and value content. The object of the study was the individual styles of students' activity; the subject - the characteristics of these styles. The goal set included the following tasks:

1) Definition of the basic styles of educational activity of students;

2) Description of the specific characteristics of the individual styles of students' activities.

The characteristics of the organization of activities were determined with the help of the questionnaires: «Questionnaire» Diagnostics of the features of self-organization-39» (Miloradova, 2005), developed by A.D. Ishkov, based on the holographic model of self-organization)" and the questionnaire "Self-organization features diagnostics" (developed by A.D. Ishkov on the basis of a holographic model of self-organization process). The results of the questionnaire provide information on the development of the following performance characteristics: goal setting, situation analysis, planning, self-control, correction and volitional efforts. To identify personal characteristics, the five-factor personality questionnaire method (R. McCray, P. Costa «Five factor model (FFM)» was chosen, which allows assessing the severity of five factors of behavioral traits (openness to experience, extraversion, neuroticism, conscientiousness, cooperation) (Khromov, 2000). Value orientations were studied using the method of studying value orientations of M. Rokich (Raigorodskii, 2004).

\section{RESULTS AND DISCUSSIONS}

Fourth-year students of the Volga State Technological University (89 people) took part in the research. The distribution of subjects by sex and age is presented in Table 1.

Table 1. Distribution of subjects by sex and age.

\begin{tabular}{|c|c|c|c|c|c|}
\hline \multirow{2}{*}{$\begin{array}{c}\text { Number of } \\
\text { the sample }\end{array}$} & Average age & $\begin{array}{c}\text { Minimum } \\
\text { age (years) }\end{array}$ & $\begin{array}{c}\text { Maximum } \\
\text { age (years) }\end{array}$ & \multicolumn{2}{|c|}{ Distribution by sex (people) } \\
\cline { 5 - 6 } & & men & women \\
\hline $\mathrm{N}=89$ & $20,5 \pm 1,6$ & 19 & 34 & 30 & 59 \\
\hline
\end{tabular}

As a method of statistical analysis, descriptive statistics were used, as well as Cluster analysis (K-means) and a t- criterion for independent samples. Data processing was carried out using statistical package Statistica 6.

Based on the clustering of data on the scales of the methodology "Diagnosis of the features of selforganization-39", two styles of activity were established. Each cluster is characterized by the specifics of the organization of activities. Activities of respondents who are in cluster 1 are more organized: they plan their activities well, analyze working conditions and control the results, and are able to correctly set goals. Respondents assigned to cluster 2 are less successful in organizing their activities. The advantage of their activity is the developed ability to correct the activity, which is at the same level of development as the respondents in cluster 1 . Thus, the style of activity of the respondents of cluster 1 can be designated as «the style of planning», and the style of activity of the respondents of cluster 2 as "style Correction» (Figure 1).

Next, we compared the average values for the personality characteristics and value orientations of students with both styles of activity (Table 2). Students, who are characterized by the style of planning, more responsibly approach the activities that they performed. The values of "diligence", "intransigence to shortcomings" and "breadth of views" are more significant for them than for students with the style of correction. At the same time, the latter value self-confidence, independence and intransigence to shortcomings, this speaks of the desire for free activity and self-expression. 

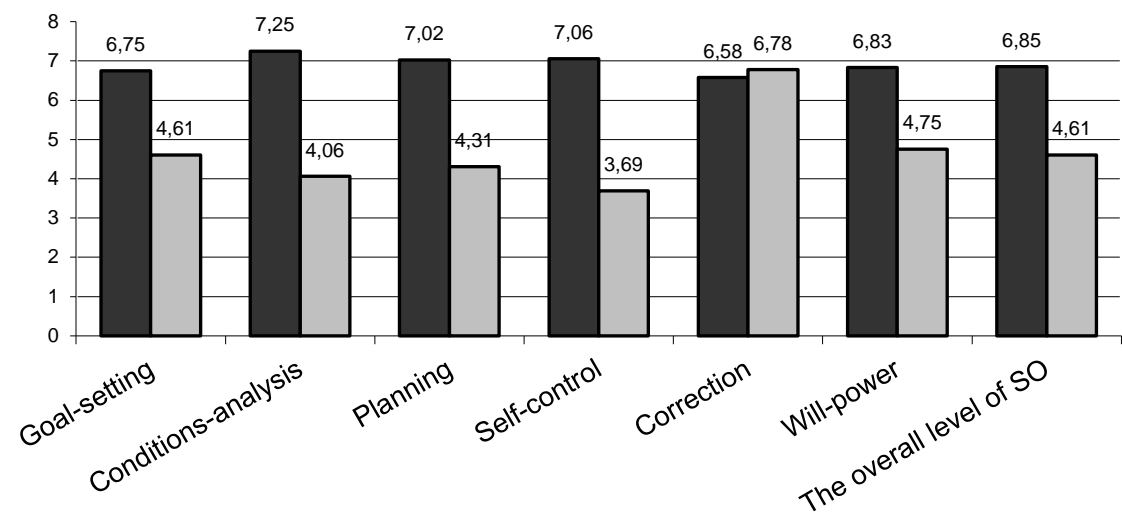

Planning style aCorrection style

Fig.1. Mean values according to the scales of the method "Diagnostics of the features of self-organization$39 "$ in clusters 1 and 2

Table 2. Significant differences in groups of students with different styles of activity.

\begin{tabular}{|c|c|c|c|c|}
\hline Scale name & $\begin{array}{l}\text { Average value in } \\
\text { the "Planning style" group } \\
\pm \text { standard deviation }\end{array}$ & $\begin{array}{l}\text { Average value in } \\
\text { the "Correction style" group } \\
\pm \text { standard deviation }\end{array}$ & $F$ & p-level \\
\hline \multicolumn{5}{|c|}{ Personal properties } \\
\hline Self-confidence & $55,9 \pm 9,1$ & $47,6 \pm 8,9$ & 1,05 & 0,000 \\
\hline \multicolumn{5}{|c|}{ Value orientations } \\
\hline Self-confidence & $9,22 \pm 4,50$ & $7,24 \pm 3,81$ & 1,39 & 0,033 \\
\hline Performance & $10,76 \pm 4,52$ & $12,65 \pm 4,18$ & 1,17 & $0,050^{*}$ \\
\hline Independence & $10,04 \pm 5,16$ & $6,43 \pm 4,33$ & 1,42 & 0,000 \\
\hline $\begin{array}{l}\text { Irreconcilability } \\
\text { to shortcomings }\end{array}$ & $15,68 \pm 3,24$ & $14,14 \pm 4,35$ & 1,80 & $0,060^{*}$ \\
\hline $\begin{array}{l}\text { Latitude } \\
\text { of views }\end{array}$ & $9,26 \pm 5,28$ & $11,22 \pm 5,07$ & 1,09 & $0,085^{*}$ \\
\hline
\end{tabular}

* - the differences are revealed at the level of the trend

\section{CONCLUSION}

Thus, as a result of the literature analysis of individual styles of activity basic approaches and trends to the study of this problem were identified and described. It is noted that the works of Russian scientists present the structure of the individual style of activity as an integral relationship of various personality traits. At the same time, foreign approaches to the style of activity are based on individual characteristics of information retrieval and processing, construction of knowledge and training. Therefore, the problem of individual style is relevant for modern educational psychology.

The results of the empirical study made it possible to identify two styles of student 's learning activities: the style of planning and the style of adjustment. Each style is interconnected with a specific group of personal qualities, which includes perseverance, foresight, self-control of behavior, accuracy and responsibility. The 
other personality traits are equally characteristic of students of both styles. In addition, the attitude towards activities affects the individual style of activity, which affects value orientations.

So, the individual style of activity is a system of different levels of personality and personality characteristics, which includes a value attitude to activity, behavioral traits and peculiarities of organizing activities in real conditions. Nevertheless, for the development of educational technologies, taking into account the individual style, a deeper study of the structure of the activity style and modeling of the dynamics of this structure at different stages of training is necessary.

\section{REFERENCE LIST}

Adler, A. (2011). The practice and theory of individual psychology. Moscow.

Andreeva, S. N., Bakhtina, S. V. (2013). Personal development of the gifted child and his problems. In A.N. Yarygin \& A.A. Korostelev, O.I. Donina (Eds.), The category of "social" in modern pedagogy and psychology materials of the Scientific and Practical Conference (correspondence) with international participation, SIMJET (Ulyanovsk).

Bakhtina, S. V., Belyanina, V. B. (2008). Studying the personality of the student. Teaching-methodical manual. Yoshkar-Ola.

Golovanova, T. N. (2004). Formation of a holistic understanding and explanation of reality through a religious and non-religious attitude towards the world. The dissertation author's abstract on competition of a scientific degree of the candidate of psychological sciences. Kazan State Technical University. A.N. Tupolev. Kazan.

Khinkanina, A. L., Serova, O. E. (2016). Characteristics of value and professional orientation of the technical university students. International Journal of Environmental and Science Education. 11 (13).

Khromov, A. B. (2000). Five-factor personality questionnaire: Study guide. Kurgan: Publishing House of the Kurgan State. University.

Klimov, E.A. (2003). Psychology of the professional. Moscow.

Lezhnina, L. V. (2007). Systematic and functional approach to the organization of psychological and pedagogical education. Higher education today, 9.

Miloradova, N. G. (2005). Psychology and pedagogy. Moscow: Gardariki.

Pakhmutova, M.A. (2015). The individual styles of research activities of modern students. Psychology of learning, 7.

Raigorodskii, D. Y. (2004). Practical psychodiagnostics. Methods and tests. Samara: Publishing House "Bahrah".

Tolochek, V. A. (2015). Activity Styles: A Resource Approach. Moscow. 